\title{
Preventive Measure for Controlling Fund Wastages and Misappropriation in Secondary Schools in South East, Nigeria
}

\author{
Dr. Isaac N. Nwankwo \\ Dept. of E.M.P. N.A.U. \& Co-coordinator \\ Research and Publication Unit \\ Ebonyi State College of Education \\ Ikwo, Ebonyi State \\ Nigeria \\ Mrs. Uduma-Chima Comfort E. \\ Ebonyi State College of Education \\ Ikwo, Ebonyi State \\ Nigeria
}

\begin{abstract}
This study ascertained preventive measures for controlling fund wastages and misappropriations in schools. One research question and one null hypothesis guided the study. The study was conducted in South East States of Nigeria using descriptive survey research design. The population of the study comprised 1241 public school principals while the sample comprised 870 principals. A questionnaire developed by the researchers duly validated by experts was used for data collection. The reliability coefficient of 0.75 was obtained using Cronbach alpha. Data were analyzed using mean, standard deviations and t-test. Findings indicated that school principals do not use preventive measures for controlling fund wastages and misappropriations. It was recommended that principals should use the preventive measures for controlling fund wastages and misappropriations.
\end{abstract}

Keywords: Preventive measure; Fund control; fund wastage; Misappropriation; and Secondary school.

\section{Introduction}

The funding of public schools in Nigeria, as it were, is the sole responsibility of the government. The underlying rationale for government funding of public schools is to provide the schools with the resources needed for training the students. Accordingly, sources of funding education in Nigeria include government subventions, donations, tuitions, levies, Tertiary Education Trust Fund (TETFund) and the internally generated revenue by the educational institutions. This varied source notwithstanding, proper fund management is still very important if the school must achieve its goals. In order to properly manage funds in the school, fund control measures must therefore be adopted.

Fund control measures, according to Okon, Ukpong and Akpan (2011) are the management measures and procedures adopted to control mismanagement of cash and other assets of the school. They further noted that fund controlling entails monitoring, comparing and correcting errors in the discharge of the duties of the accounting staff. Thus, the objective of controlling fund in the context of this study is to prevent financial frauds. According to Holmes (2000), fund control measures in any organization helps in regulating the spending of money and reveals losses, wastes and inefficiency, thus making it possible for corrections to be made promptly. Accordingly, Bratim (2014) and Sarka (2010) categorized fund control measures into three namely: preventive; detective and corrective mechanisms. The focus of this study is on the preventive mechanisms. In fund management, preventive control mechanism entails budget implementation, and the functions of preventive measures include spotting financial problems before they arise, making adjustments, preventing financial errors, omissions or malicious acts from occurring (Ukpong 2006).

Preventive measures according to Nelson (2013) are the most effective types of internal controls that are put in place before errors or irregularities occur and are designed to keep flaws from happening. Examples of preventive measures according to him are budget implementation; adequate separation of duties; which implies not having the same person both as disburser of fund and auditor in the school business transactions. 
Preventive measures also include proper authorization of transactions, proper reviewing and approving of purchase request and adequate documentation and control of assets when purchases are made. The measurer's also emphasized that there should be approved purchase requests, invoices and receiving documents to show delivery of the items. In this regard, preventive measures operate a proactive capacity to deter or prevent undesirable activities (Rothberg, 2011).

In the context of this study, preventive measures for controlling fund wastages and misappropriations consist of appropriate monitoring of procedure at key periods of their development in order to allow early detection of financial fraud and results in adequate early warning and early reaction. The preventive mechanisms for controlling fund wastages and misappropriations aim at reducing occurrence and intensity of negative outbreaks of fund wastages and misappropriations.

In the light of the above, financial frauds in the school system can be prevented through effective budget implementation. In secondary schools for instance, principals are the main accounting officers. They are not only expected to prepare the school budget, they are to follow the government's financial regulations in the preparation and implementation of the budget. In the financial regulations of the Federal Republic of Nigeria (FRN, 2009: 112-113), some of the major functions of accounting officers include:

- ensuring that proper budgetary and accounting systems are established and maintained to enhance internal control, accountability and transparency,

- ensuring that the essential management control tools are put in place to minimize waste and fraud;

- ensuring accurate collection and accounting for all public money received and expended;

- ensuring prudence in the expenditure of public funds;

- ensuring proper assessments, fees, rates and charges are made where necessary;

- ensuring internal guides, rules, regulations, procedures are adequately provided for the security and effective check on the assessment, collection and accounting for revenue;

- ensuring that any losses of revenue are promptly reported and investigated.

- ensuring that any revenue collected are not spent, but remitted to the appropriate authorizes promptly.

The above regulations guide the financial activities of every accounting officer in public service in Nigeria. As public servants, secondary school principals are expected to be guided by the financial regulations in the management of public funds entrusted to their care. A critical examination of the functions of accounting officers reveals that they expressed the preventive mechanisms for the control of fund wastages and misappropriations.

According to Omenyi, Nwankwo and Onuma (2015), principals are financial managers in secondary schools and their financial roles include organizing the school staff, preparing the school budget, administering capital outlay and debt services, administering school purchases, accounting for school monies and property and providing for a system of internal accounting. They further observed that though school bursars are appointed to head the financial section of the schools, principals influence the provision of funds and facilities through proper accounting, reporting and effective negotiations during budgeting.

Like other budgeting practices, secondary school budgets follow a systematic procedure, which, according to Oboegbulem and Kalu (2013), includes budget planning, budget defence, budget approval and adoption, budget implementation and budget evaluation. Due to the organizational structure of secondary schools in Nigeria, school principals are not involved in all the stages of budgeting (Hassan 2009). According to Nzekwe (2007) principals are highly engaged in the planning, defence and implementation stages while the Secondary Education Management Board and Ministry of Education carry out budget approval, adoption and evaluation. The Ministry of Education and Secondary Education Management Board do these jobs through the financial supervisors who monitor and verify the financial activities of the school principals (Oboegbulem \& Kalu 2013).

As noted above, there is systematic budget procedure in the school system, but Nzekwe (2007) and Onyike (2009) are not comfortable with the management measures for the control of fund wastages and misappropriation in the secondary schools. For instance, Oboegbulem and Kalu (2013) observed that many principals in Nigeria had been accused by supervisors, teachers and parents of poor budgeting practices and financial frauds. According to Nzekwe (2007), many principals do not follow budget procedures in planning and implementing of budget nor keep and use the necessary financial account records in their schools. Supporting this fact, Onyike (2009) regretted that fund wastages and misappropriations have accounted for the seeming neglect and dilapidation of buildings and infrastructure in secondary schools in Nigeria, South East States inclusive. 
In the same manner, diversion and embezzlement of funds seem to have become the order of the day in the country's educational sector. There has been an allegation that funds even when released are lodged in the banks and fake names are finally given to scoop up remaining funds as "ghost workers". Omoniwa (2002), identified "poor funding and management" as the most serious problems to the educational system in Nigeria today. In agreement with the above is the view of Ogbonnaya (2000:24) that: Some officials divert funds earmarked for erection of classroom blocks into games and sports. Some others are known to insist on gratification for every task to be accomplished or any project to be undertaken. Some administrators receive gratification for the award of contract concerning the construction of science laboratories or the procurement of teaching equipment.

In South East States of Nigeria, most secondary schools are not in good shape. Onyechere (2005), observed that embezzlement of funds and infrastructural decays were recorded in most secondary schools in the State. The embezzlement of funds in the state has resulted in financial problem. According to Omenyi, Nwankwo and Onuma (2015), in order to solve the financial problems in secondary schools in South East States of Nigeria the Governors in the area donated millions of naira and distributed buses, generators and computers to secondary schools in the area. Despite these financial donations, most secondary schools in the area are still faced with financial problems as evidenced in dilapidated infrastructure and absence of current teaching facilities (Omenyi, Nwankwo \& Onuma 2015). In view of the above, this study ascertained the preventive measures for controlling fund wastages and misappropriations in secondary schools in South East States of Nigeria.

Research Question: What are the preventive measures for controlling fund wastages and misappropriation in secondary schools in South East States of Nigeria?

Hypothesis: Male and female secondary school principals do not differ significantly in their mean ratings on preventive measures for controlling fund wastages and misappropriations in Secondary Schools in South East States of Nigeria.

\section{Conceptual Clarifications}

\section{Fund Management and Fund Control}

Fund management means applying general management principles to the financial resources of an institution. This entails planning, organizing, directing and controlling the financial activities such as procurement and utilization of funds of the institution. Nwadiani (2000) viewed fund management as the managerial planning and control of financial resources of a business to achieve the objective of the business. Nwadiani further stated that fund management principally deals with keeping accounting records and reports, obtaining funds, monitoring cash positions and paying bills. Comprehensively, fund management is concerned with strategic financial decisions within an organization, and its importance stems from the scarcity of resources. The people, material and financial resources needed to achieve the objectives of every institutions are limited, hence there is need to manage their utilization in other to attain whatever goal that is set.

Ogbonnaya (2012) conceptualized fund management as that management activity which is concerned with the planning and controlling of an organization's financial resources. One can deduce from these definitions, that fund management is concerned with decisions on how to procure, expend and give accounts of funds provided for the implementation of programmes in an organization.

Nwagwu (2000) viewed fund management as an embodiment of all the basic functions involved in administration of funds ranging from planning to the auditing of the organization's accounts. Fund management is not only concerned with working out means of obtaining fund, but also emphasizes the judicious use of the fund as well as keeping accurate accounts of how the fund was used. The judicious use of fund and accurate accounting of such fund acts as a reference point on assessing the current performance of the organization as well as making necessary and informed forecast on the future needs and performance of an organization.

In this study fund management is perceived as the act of being responsible for obtaining and effectively utilizing the funds generated in an institution. Efficient operation of an organization hinges sufficiently on fund management which are fund raising and the effective use of same to achieve objectives. Financial management has functions which include the review and control of decisions to plan, expend, disburse, utilize and give account of funds so used. Adams (2006) revealed that, good financial management minimizes risks associated with finance such as internal control risks, operating risk and off-balance sheet risk. Adequate financial management helps to easily actualize the objective of internal control, facilitating efficient performance, within established operating policies, ensuring the reliability, adequacy and timelines of financial information. 
This corroborates Arikewuyo (2004) who explained that financial management is used for reporting and decision making, safeguarding assets, complying with generally accepted accounting principles, preventing or discouraging errors and irregularities.

Fund management will, to a large extent, help the financial managers in excellent and efficient handling of the flow of funds which will in the long run result to a sound success in the institutions. Fund management emphasizes accountability in the school or organization. Accountability here refers to answerability for ones action or behaviour.

Accountability involves answerability, responsibility, control, productivity and evaluation (Onokerhoraye \& Nwoye, 1995). Fund management as conceptualized in this study does not involve only getting money and spending it but also organized and judicious fund planning and execution of plan. The success of every educational institution depends on this judicious planning and execution of the plan.

\section{Preventive Measures}

Preventive measures according to Nelson (2013), are the most effective types of internal controls that are put in place before errors or irregularities occur and are designed to keep flaws from happening. Examples of preventive measures according to him are budget implementation; adequate separation of duties; which implies not having the same person both as author and process transactions proper authorization of transactions where a supervisor authorizes a purchase by reviewing and approving the purchase request and adequate documentation and control of assets when purchases are made. There should be an approved purchase request and an invoice and receiving documents to show delivery of the items.

In line with the above is the assertion of Rothberg (2011) that preventive measures as the name would suggest, operate a proactive capacity to deter or prevent undesirable activities. He added that such measures might include the segregation of accounting duties, regulations implement requiring proper authorization or documentation of budget and physical control over company assets.

The above views validates Kyrgyzstan (2008), who highlighted that preventive measures consist of appropriate monitoring of procedure at key periods of their development in order to allow early detection of number, increase and behaviour change, and results in adequate early warning and early reaction. It aims at reducing occurrence and intensity of negative outbreaks in an organization and preventing their development into major upsurges.

Throwing more light on the concept, the Institute of Chartered Accountants of Nigeria (ICAN, 2006) observed that preventive measures are controls that predict potential problems before they occur and make adjustments. They also prevent an error, omission or malicious act from occurring. Examples of preventive measures according to the body include using well-designed documents to prevent errors, establishing suitable procedures for authorization of transactions, and employing only qualified personnel.

From the above expositions, the researchers conceptualize preventive measures as activities aimed at deterring the instance of errors or fraud in an organization. These activities include thorough documentatic Id authorization practices, which prevent undesirable activities from happening.

\section{Research Method}

The area of the study was South East States of Nigeria. The descriptive survey research design was adopted. The population of the study comprised all the one thousand two hundred and forty one (1241) public secondary school principals in the area of the study. The sample of this study comprised 870 principals who represent seventy percent $(70 \%)$ of the entire population. A questionnaire developed by the researchers was used for data collection. The instrument is titled "Fund Wastage and Misappropriation Control Questionnaire" (FWMCQ). The face and content validity of the instrument were determined three experts.

The reliability of the instrument was determined by administering copies of the questionnaire on 20 principals of secondary schools in South-South zone of Nigeria. The reliability coefficient of 0.75 was obtained using Cronbach alpha to determine the internal consistency of the items.

The researchers together with the help of research three assistants administered the instrument directly to the respondents in the five states that make up the South East of Nigeria. The research assistants were instructed on how to distribute and collect copies of the questionnaire from the respondents. Mean scores and standard deviations were used to answer the research question while t-test was used to test the hypothesis at 0.05 level of significance. 


\section{Presentation of Results}

Research Question: What are the preventive measures for controlling fund wastages and misappropriation in Secondary Schools in South East States of Nigeria?

Table 1: Mean Rating of Principals on Preventive Measures for Controlling Fund Wastages and Misappropriation

\begin{tabular}{|c|c|c|c|c|c|c|c|}
\hline SN & $\begin{array}{l}\text { Items on Preventive Measures for Controlling Fund } \\
\text { Wastages and Misappropriation }\end{array}$ & $\begin{array}{l}(\overline{\mathbf{x}}) \\
\text { Princ. } \\
( \\
\text { Male) }\end{array}$ & Sd & Rmk & $\begin{array}{l}\quad(\overline{\mathbf{x}}) \\
\text { Princ. } \\
( \\
\text { Female) }\end{array}$ & Sd & Rmk \\
\hline 1 & $\begin{array}{l}\text { I use well designed budgeting document to prevent loss of } \\
\text { fund. }\end{array}$ & 2.30 & 0.12 & $\mathrm{D}$ & 1.52 & 0.11 & $\mathrm{D}$ \\
\hline 2 & I surcharge officer responsible for loss of cash in the office. & 2.52 & 0.09 & A & 3.40 & 0.10 & A \\
\hline 3 & $\begin{array}{l}\text { I make immediate report to the ministry any time loss of } \\
\text { cash occurs in the office. }\end{array}$ & 2.54 & 0.11 & A & 2.34 & 0.09 & A \\
\hline 4 & $\begin{array}{l}\text { I ensure that school projects reach a specified stage before } \\
\text { releasing another fund. }\end{array}$ & 1.39 & 0.11 & $\mathrm{SD}$ & 1.45 & 0.11 & $\mathrm{SD}$ \\
\hline 5 & $\begin{array}{l}\text { I request account for funds released for school projects } \\
\text { before releasing another. }\end{array}$ & 1.21 & 0.10 & $\mathrm{SD}$ & 1.38 & 0.09 & SD \\
\hline 6 & $\begin{array}{l}\text { I perform oversight functions in the schools based on } \\
\text { control objectives. }\end{array}$ & 1.09 & 0.12 & $\mathrm{SD}$ & 1.48 & 0.10 & SD \\
\hline 7 & $\begin{array}{l}\text { I report to the police any suspected financial theft in the } \\
\text { office. }\end{array}$ & 1.05 & 0.11 & SD & 1.31 & 0.08 & $\mathrm{SD}$ \\
\hline 8 & $\begin{array}{l}\text { I initiate immediate action by completing treasury form } \\
146 \text { whenever financial loss occurs in the office. }\end{array}$ & 1.08 & 0.10 & $\mathrm{SD}$ & 1.05 & 0.12 & SD \\
\hline 9 & $\begin{array}{l}\text { I credit any recovered amount from a declared loss to the } \\
\text { non-personal advances account initially charged. }\end{array}$ & 1.94 & 0.11 & $\mathrm{D}$ & 1.78 & 0.10 & $\mathrm{D}$ \\
\hline 10 & $\begin{array}{l}\text { I credit surcharged amount to the miscellaneous revenue } \\
\text { head of the current years estimate. }\end{array}$ & 1.91 & 0.12 & $\mathrm{D}$ & 1.62 & 0.11 & $\mathrm{D}$ \\
\hline 11 & $\begin{array}{l}\text { I ensure authorization and approval of school funds before } \\
\text { they are spent. }\end{array}$ & 2.55 & 0.10 & A & 2.68 & 0.10 & A \\
\hline \multirow[t]{2}{*}{12} & I ensure conformity with budget stipulations. & 1.51 & 0.11 & $\mathrm{D}$ & 2.30 & 0.12 & $\mathrm{D}$ \\
\hline & Mean of Means & $\mathbf{1 . 7 6}$ & $\mathbf{0 . 1 1}$ & $\mathbf{D}$ & 1.02 & $\mathbf{0 . 1 0}$ & SD \\
\hline
\end{tabular}

The results on table 1 indicated the mean ratings of principals on preventive measures for controlling fund wastages and misappropriation in secondary schools in South East States of Nigeria. Both male and female principals agreed to items 2, 3 and 11 as preventive measures for controlling fund wastages and misappropriations in secondary schools in South East States of Nigeria. They disagreed on items 1, 9, 10 and 12 as preventive measures for controlling fund wastages and misappropriations in secondary schools in South East States of Nigeria. In the same manner, items 4, 5, 6, 7, and 8 were rated strongly disagreed by both respondents. Again, the standard deviations for male principals range between 0.10 and 0.12 to show non-variability of the mean ratings. In the same manner, those of female principals range between 0.08 and 0.12 to indicate the cluster of the ratings around the mean.

The mean of means for male principals is 1.76 with sd. of 0.11 indicating they disagree on the items as preventive measures for controlling fund wastages and misappropriation in secondary schools. Again, the mean of means for female principals is 1.02 with sd. of 0.10 indicating that they strongly disagree on the items as preventive measures for controlling fund wastages and misappropriation in secondary schools. Thus, they do not use preventive measures in controlling fund wastages and misappropriation.

Testing Hypothesis: Male and female secondary school principals do not differ significantly in their mean ratings on preventive measures for controlling fund wastages and misappropriations in Secondary Schools in South East States of Nigeria. 
Table 2: t-test summary of mean ratings of Principals on Preventive Measures for Controlling Fund Wastages and Misappropriations

\begin{tabular}{lllllllll}
\hline $\begin{array}{l}\text { Source of } \\
\text { variation }\end{array}$ & Number & Mean & $\mathrm{Sd}$ & $\mathrm{df}$ & $\mathrm{t}$-cal & $\mathrm{t}$-crit & $\mathrm{P}$ & Decision \\
\hline $\begin{array}{l}\text { Principals } \\
\text { (Male) }\end{array}$ & 472 & 1.76 & 0.11 & & & & & Not significant \\
$\begin{array}{l}\text { Principals } \\
\text { (Female) }\end{array}$ & 398 & 1.02 & 0.10 & & & & & \\
\hline
\end{tabular}

As show on table 2, the calculated $\mathrm{t}$-value of 2.28 is greater than the critical $\mathrm{t}$-table value of 1.960 at 868 degree of freedom and 0.05 level of significance. This hypothesis is therefore not significant. Thus, male and female secondary school principals differ significantly in their mean ratings on the preventive measures for controlling fund wastages and misappropriations in Secondary Schools in South East States of Nigeria.

\section{Summary of Findings}

From the analysis of data, the following summary of major findings was made:

1. Secondary school principals do not use preventive measures for controlling fund wastages and misappropriations in South East States of Nigeria.

2. Male and female secondary school principals differ significantly in their mean ratings on the preventive measures for controlling fund wastages and misappropriations in Secondary Schools in South East States of Nigeria.

\section{Discussions of Findings}

Data analysis for the research question revealed that secondary school principals in South East States of Nigeria do not use the preventive measures for controlling fund wastages and misappropriations. The tested hypothesis revealed that male and female secondary school principals differ significantly in their mean ratings on the preventive measures for controlling fund wastages and misappropriations in Secondary Schools in South East States of Nigeria.

The findings of this study are revealing. In schools or situations where preventive measures for controlling fund wastages and misappropriations are used, it is most likely that a lot of funds might either be wasted or misappropriated. The result might be insufficient fund for the actual running of the schools. In secondary schools in South East States of Nigeria, most secondary schools seem not to have enough funds to take care of the day-today running of the schools. This does not mean that the state governments have not provided the funds. The inference to be drawn here is that necessary preventive measures have not been adopted to check fund wastages and misappropriations in the secondary schools. This affirms earlier findings by Onyechere (2005) that most secondary schools in secondary schools in South East States of Nigeria were characterized by embezzlement of funds and infrastructural decays.

The findings of this study are in agreement with Alagbu (2004) who found that funds allocated for secondary education in some states in South East of Nigeria were wasted through questionable means such as inflation of contracts to benefit some officials in the Ministry of Education. This was allowed to happen probably because adequate preventive measures were not taken to control fund wastages and misappropriations in the area. In the same manner, Kalu (2013) found significant difference in the mean ratings of principals and account supervisors on measures used to prevent fund wastages and embezzlement in secondary schools in South-East, Nigeria.

\section{Conclusion}

Based on the findings of the study, it is concluded that secondary schools in South East States of Nigeria do not use preventive fund management measures for controlling fund wastages and misappropriations. Male and female principals differed significantly in their mean ratings on the extent of preventive measures used for controlling fund wastages and misappropriations in the secondary schools.

\section{Implications of the Study}

The first implication is for the school principals. 
Findings of this study revealed the principals do not use the preventive fund management measures for controlling fund wastages and misappropriations in the secondary schools. The implication is that the absence of effective or adequate management control measures may likely create avenues for corrupt financial managers in the school system to misappropriate or waste school funds. School principals can control fund wastages and misappropriations in their schools by effectively using the preventive mechanisms. If they do not use them, it is most likely that the schools will lose a lot of funds through fund wastages and misappropriations. This can hamper its ability to accomplish its mission and to attract additional funds from either the government or private sector organizations or individuals. Thus, if the principals do not use the measures, educational objectives will be difficult to achieve at the secondary education level.

Another implication of the findings is for the Ministries of Education. Since this study found that the principals do not use the management measures for controlling fund wastages and misappropriations in their secondary schools, it implies that the efforts of the Ministries to ensure proper management of funds in secondary schools in the respective states can be sabotaged by corrupt school principals. Accordingly, the Ministries can put adequate measures by setting up a monitoring team to ensure that principals use the necessary preventive measures for controlling fund wastages and misappropriation in the secondary schools. This may likely go a long way in checking fund wastage and misappropriation in secondary schools in South East State of Nigeria.

The last implication of the findings is for the state governments. The State governments in South East State of Nigeria have spent a lot of money on secondary schools in the area, yet most of the schools are still characterized by infrastructural decays. If adequate measures such as effective monitoring and auditing are not put in place and enforced by the respective state governments to check fund wastages and misappropriations, it is most likely that funds given to the schools might be wasted or misappropriated by corrupt school managers.

\section{Recommendations}

Based on the results of this research, the following recommendations are made:

1. Secondary school principals in South East State of Nigeria should use the preventive measures for controlling fund wastages and misappropriations.

2. The State Ministries of Education in various states in South East State should put in place measures that will compel school principals to adopt the measures for controlling fund wastages and misappropriations as found in this study. One of such mechanism is to ensure that the provided financial regulations are complied with, and that there are consequences for failure to comply with the provisions.

3. The respective state government should set up a special audit and monitoring group to ensure that school principals use the management measures for controlling fund wastages and misappropriations as found in this study.

4. The respective state government should mandate its Ministry of Finance and Ministry of Education in the state to organize workshops and seminars for school principals on the preventive measures for controlling fund wastages and misappropriations.

5. The respective State Ministry of Education should investigate and prosecute any case of fund wastage or misappropriation in secondary schools in its state. This will serve as a deterrent to principals that are yet to adopt the management measures.

\section{References}

Alagbu, C.N. (1993). A comparative study of the administrative and organization of Federal and State secondary schools in Anambra State, unpublished M.Ed thesis, Ahmadu Bello University, Zaria.

Arikewuyo, M.O. (2004). Democracy and university education in Nigeria: Some constitutional considerations, higher education management and policy. Journal of the Organization for Economic Co-operation and Development (OECD) 16, 121-134.

Bratim, T. (2014). Modern leadership for changing times. Buckingham: Open University Press.

Federal Republic of Nigeria (FRN, 2009). Financial Regulations and Allied Laws. Abuja: LawLords Publications.

Hassan, T. (2009). A case for improving quality assurance of high education in Bayelsa State. NAEAP, Pages 271-278.

Holmes, B. (2000). Principles of funding secondary schools. New Relhi: Summit Enterprises. 
Institute of Chartered Accountant of Nigeria (ICAN, 2006). Principle of financial accounting. Lagos: ICAN.

Kalu, P. (2013). Ifekandu, S.K. (2003). Effects of bargaining strategy and mode of dressing or, bargaining outcomes in Ibadan Markets. An Unpublished Ph.D Dissertation, Ibadan.

Kyroyzstan, R. (2008). Quality assurance in secondary education programme of Bangladesh Open University: present Studies and challenges. Turkish Journal of Distance Education. 9 (2) 35-43.

Nelson, R. W. (2013).Motivation through funding. Psychological Review, 62, 5, p. 298-335.

Nwadiani, M. (2000). Economic dimension of educational planning in Nigeria. Theory and practice. Benin City: Monose Amalgamates.

Nwagwu, N.A. (2000). Funding and financial management in Nigeria tertiary institutions. Nsukka: Institute of Education.

Nzekwe, S.A. (2007). Classroom management and teaching of social studies. Journal of Education and practice. $5(16)$

Obaegbulem, A.\& Kalu O. (2013). A handbook on school administration and management. McMillan Nigeria Publisher, Ibadan.

Ogbonnaya, N.I. (2000). Foundations of education finance. Onitsha: Cape Publishers International Ltd.

Ogbonnaya, N.O. (2012). Foundations of education finance. Nsukka: Hallman Publishers.

Okon, D.I. Ukpong, J.C \& Akpan, S.A (2011). Classroom management and teaching of social studies. Journal of Education and practice. 5(16)

Omenyi, A. S. Nwankwo, I. N. \& Onuma, N. (2015). Analysis of public and private secondary school principals' financial management in the implementation of entrepreneurship studies in Anambra State. paper presented at the $34^{\text {th }}$ Annual Conference of NAEAP, University of Benin Auditorium, Benin City; Tuesday $6^{\text {th }}-9^{\text {th }}$ October, 2015.

Omoniwa, M.A. (1982, October 20). "Financing and managing our educational system", Nigeria Standard. Pp.3.

Onyechere, M. (2005). Supervisory behavior and teacher satisfaction in secondary school. Nigeria Journal of Educational Management 7, 1-12.

Onyike, T. (2009). Fundermentals of educational administration and planning. Enugu: Magnet Business Enterprise.

Rothberg, D. (2011). Class and Class Conflict in Industrial Society. California: Stanford University Press.

Sarka, D. (2010). Financial accounting, Personal and Professional Development. New Jersey: Prentice-Hall, Inc.

Ukpong, J.H. (2006). Introduction to educational finance administration in Nigeria. Ibadan: Spectrum books. 